\title{
The Role of Mental Toughness and Intrinsic Motivation on Athletes' Resilience During the Covid-19 Pandemic
}

\author{
Hermahayu \\ Department of Psychology, Universitas Muhammadiyah Magelang, Indonesia \\ hermahayu@ummgl.ac.id \\ https://doi.org/10.53017/ujsah.54
}

Received: 23/06/2021

Revised: 29/06/2021

Accepted: 30/06/2021

\begin{abstract}
The Covid-19 pandemic is a global problem that has disrupted and delayed several national and international sports competitions. Athletes face the direct psychological consequences of Covid-19 such as cancellation of competitions, loss of support, lack of training, loss of income, excessive vigilance, and anxiety. Therefore, this study aims to examine the relationship between resilience, mental toughness, and intrinsic motivation in national competitive athletes in Central Java, Indonesia during the pandemic. A total of 225 athletes from 23 sports who have participated in various nationally standardized competitions were involved in this study. The results showed that resilience was positively related to mental toughness $(r=0.616)$ and also to intrinsic motivation $(r=0.466)$. Mental toughness and intrinsic motivation, significantly predict resilience $\left(R^{2}=0.393\right)$. The findings of this study contribute that developing a mental toughness mindset and strengthening athletes' intrinsic motivation can represent intervention targets for resilient adaptation programs in the face of an uncertain pandemic situation.
\end{abstract}

Keywords: Covid 19; Mental toughness; Intrinsic motivation; Athletes' resilience

\section{Peran Ketangguhan Mental dan Motivasi Intrinsik Terhadap Resiliensi Atlet Selama Pandemi Covid-19}

\begin{abstract}
Abstrak
Pandemi Covid-19 adalah masalah global yang telah mengganggu dan menunda beberapa kompetisi olahraga nasional dan internasional. Atlet menghadapi konsekuensi psikologis langsung dari Covid-19 seperti pembatalan kompetisi, kehilangan dukungan, kurangnya pelatihan, kehilangan pendapatan, kewaspadaan berlebihan, dan kecemasan. Oleh karena itu, penelitian ini bertujuan untuk menguji hubungan antara resiliensi, ketangguhan mental, dan motivasi intrinsik pada atlet kompetitif nasional di Jawa Tengah, Indonesia selama pandemi. Sebanyak 225 atlet dari 23 cabang olahraga yang telah berpartisipasi dalam berbagai kompetisi terstandar nasional terlibat dalam penelitian ini. Hasil penelitian menunjukkan bahwa resiliensi berhubungan positif dengan ketangguhan mental $(r=0,616)$ dan juga dengan motivasi intrinsik $(r=0,466)$. Ketangguhan mental dan motivasi intrinsik, secara signifikan memprediksi resiliensi $\left(\mathrm{R}^{2}\right.$ $=0,393)$. Temuan penelitian ini memberikan kontribusi bahwa mengembangkan pola pikir ketangguhan mental dan memperkuat motivasi intrinsik atlet dapat mewakili target intervensi untuk program adaptasi yang tangguh dalam menghadapi situasi pandemic yang tidak menentu.
\end{abstract}

Kata-kata kunci: Covid 19; Ketahanan mental; Motivasi intrinsik; Ketahanan atlet 


\section{Pendahuluan}

Mewabahnya Covid-19 telah menyebabkan pandemi di seluruh dunia. Hal ini memengaruhi kondisi ekonomi, sosial, dan pendidikan. Untuk menghentikan penyebaran penyakit, tindakan pembatasan yang diambil oleh sebagian besar pemerintah telah mengganggu kehidupan sehari-hari masyarakat, tak terkecuali dalam bidang olahraga. Situasi pembatasan yang dialami di seluruh dunia telah menyebabkan banyak atlet menyesuaikan pelatihan olahraga mereka tanpa alat atau ruang yang sesuai untuk mengembangkan rutinitas pelatihan mereka dengan baik. Di samping itu, pembatasan yang diterapkan oleh otoritas kesehatan, membuat sejumlah kompetisi olahraga nasional dan internasional telah ditunda atau dibatalkan dalam upaya untuk membatasi penyebaran virus.

Karena kebijakan pemerintah yang khusus dan tiba-tiba terhadap Covid-19 ini tidak terduga bagi sebagian besar populasi, langkah-langkah pembatasan mungkin menyebabkan situasi isolasi yang tidak diinginkan. Kondisi ini dapat menyebabkan konsekuensi negatif pada tingkat emosional, kognitif, dan perilaku. Periode ketidakaktifan, isolasi dari tim cabang olahraga, jarak dari komunitas olahraga, interaksi yang kurang berkualitas dengan pelatih, dan kurangnya dukungan sosial, juga telah terbukti menyebabkan tekanan emosional dan gangguan psikologis pada atlet [1]. Temuan menunjukkan bahwa pandemi Covid-19 dan pembatasan kegiatan telah membuat atlet mengalami kondisi yang sangat mirip dengan pensiun paksa.

Bagi sebagian besar atlet, berbagai gangguan mendadak ini akan membuat mereka menetapkan tujuan baru selama situasi tersebut. Bagi atlet yang berada di akhir tahap kompetitif mereka, itu bisa berarti menutup karier mereka secara dini dan tiba-tiba, yang dapat meningkatkan emosi tidak menyenangkan selama pembatasan tersebut. Penelitian menunjukkan bahwa situasi ini dapat memiliki efek psikologis yang merugikan seperti gejala stres pasca-trauma, kebingungan, dan kemarahan [2]. Studi lain juga menunjukkan bahwa pembatasan dapat memengaruhi kesejahteraan dengan mendorong, mengarahkan, atau meningkatkan penyalahgunaan zat [3].

Beberapa atlet mungkin dapat mengembangkan potensi diri untuk mengatasi kondisi tak terduga ini. Akan tetapi, sebagian atlet lain mungkin mengalami respons negatif selama beberapa minggu hingga berbulan-bulan. Hasil penelitian menemukan bahwa individu dapat merespon secara berbeda terhadap tekanan emosional yang disebabkan oleh peristiwa traumatis seperti pandemi ini [4]. Penelitian menyarankan resiliensi sebagai ciri kepribadian yang dapat membantu individu untuk mengatasi efek psikologis negatif dari peristiwa traumatis, termasuk pandemi Covid [5].

Resiliensi diistilahkan sebagai cara untuk memfasilitasi kemampuan adaptasi. Pandemic Covid 19 dan pembatasan kegiatan berskala nasional telah mengakibatkan berbagai kesulitan. Situasi ini termasuk dalam keadaan kesulitan atau penderitaan yang terkait dengan kemalangan, trauma, kesusahan, kesulitan, atau peristiwa tragis. Konseptualisasi kesulitan ini sesuai dengan posisi teoretis, yang memandang pandemi COVID-19 sebagai peristiwa perubahan dalam karier olahraga yang menyusahkan, menurunkan, dan situasi yang sulit. Situasi inilah yang membutuhkan kemampuan adaptasi atau resiliensi. Resiliensi psikologis merupakan peran proses mental dan perilaku dalam mempromosikan aset pribadi dan melindungi individu dari potensi efek negatif dari stres [6].

Pada konteks olahraga, resiliensi olahraga adalah proses dinamis dalam beradaptasi dengan lingkungan, interaksi dominan, yang mencakup kapasitas metakognitif-emosionalperilaku individu olahraga untuk mempertahankan keseimbangan positif dan berhasil 
beradaptasi dengan beragam kesulitan terkait olahraga [7]. Akademisi telah memberikan pendekatan tentang bagaimana resiliensi digunakan atau dapat digunakan dalam menanggapi gangguan yang disebabkan oleh Covid-19 [8], [9].

Resiliensi didefinisikan sebagai proses negosiasi, adaptasi, atau pengelolaan sumber stres atau trauma yang signifikan secara efektif [10]. Aset dan sumber daya dalam individu, kehidupan dan lingkungan mereka memfasilitasi kapasitas ini untuk beradaptasi dan bangkit dalam menghadapi kesulitan. Resiliensi adalah proses psikososial yang stabil secara temporal tetapi dinamis yang terungkap dari waktu ke waktu [6], [11]-[13]. Banyak faktor yang berperan dalam resiliensi seperti dukungan sosial yang dirasakan/dialami [14], rasa makna [15], iklim motivasi [16], dan ketangguhan mental [17].

Ketangguhan mental mengacu pada kumpulan karakteristik psikologis yang merupakan pusat kinerja yang optimal. Atlet, pelatih, dan psikolog olahraga secara konsisten mengimplikasikan ketangguhan mental sebagai salah satu karakteristik psikologis terpenting yang terkait dengan kesuksesan dalam olahraga. Telah diakui bahwa efek stres berpotensi merusak kesehatan mental dan fisik atlet, dan karenanya, resiliensi dan ketangguhan mental sama-sama dianggap penting untuk berhasil menangani stresor atau menghindari efek stres saat atlet mengejar prestasi yang optimal [6].

Akan tetapi, ketangguhan mental dan resiliensi sering dianggap tumpang tindih. Namun sejumlah literatur menyampaikan bahwa ketangguhan mental dan resiliensi, bagaimanapun, berbeda dalam beberapa hal. Ada pernyataan bahwa resiliensi berlaku terutama untuk konteks negatif, sedangkan ketangguhan mental juga berlaku untuk keadaan positif [18]. Ketangguhan mental mewakili satu set atribut pribadi yang mempengaruhi cara di mana kesulitan, tantangan, dan tujuan dinilai dan didekati [19]. Resiliensi, di sisi lain, mencakup berbagai kualitas yang berpengaruh dari luar diri (misalnya, dukungan sosial yang dirasakan [6].

Disamping ketangguhan mental, resiliensi atlet dalam menghadapi kesulitan juga diduga terkait dengan motivasi. Ada beberapa penelitian yang mengeksplorasi prinsipprinsip spesifik resiliensi dan motivasi di kalangan atlet. Hubungan motivasi dan resiliensi dimoderatori oleh status atlet. Secara khusus, ditemukan bahwa ada hubungan positif antara motivasi berprestasi dan resiliensi di kalangan atlet mahasiswa [20]. Penelitian lain juga telah mempelajari ketangguhan mental dan prestasi olahraga di kalangan atlet mahasiswa, yang mana ketangguhan mental yang tinggi dikaitkan dengan motivasi intrinsik yang lebih besar di antara para atlet [21]. Oleh karena itu, penelitian ini ingin melihat peran ketangguhan mental dan motivasi, khususnya motivasi intrinsic terhadap resiliensi pada atlet kompetitif di jawa Tengah dalam menghadapi situasi pandemic Covid 19.

\section{Metode}

\subsection{Partisipan}

Total ada 225 atlet yang terlibat dalam penelitian ini (90 putri, 135 putra) dari 23 cabang olahraga yang dikelola Kementerian Pemuda, Olahraga, dan Pariwisata Provinsi Jawa Tengah dan Komite Olahraga Nasional Indonesia Provinsi Jawa Tengah. Subyek penelitian berusia 13 sampai 33 tahun, dan merupakan atlet yang mengikuti kejuaraan nasional. Para atlet tersebut tergabung dalam beberapa tim olahraga, antara lain Pembinaan Sentra Olahraga Jangka Panjang (PSOJP), Pusat Pendidikan dan Latihan Olahraga Pelajar (PPLOP), Pusat Pendidikan dan Pelatihan Olahraga Mahasiswa (PPLM), dan Pusat Pelatihan Daerah PON (Pelatda PON). 


\subsection{Instrumen}

Resiliensi diukur menggunakan adaptasi the brief resilience scale (BRS) [22] yang terdiri dari 6 item. Skala ini menggunakan model jawaban Likert dengan enam pilihan respon, mulai dari 1 yang menunjukkan "sangat tidak sesuai" sampai dengan 6 yang menunjukkan "sangat sesuai". Nilai koefisien reliabilitas alpha Cronbach 0,725.

Ketangguhan mental diukur menggunakan adaptasi the Sports Mental Toughness Questionnaire (SMTQ) [23]. Skala ini terdiri dari 14 item yang terbagi menjadi tiga subskala yaitu confidence, constancy, dan control. Skala menggunakan model jawaban Likert dengan enam pilihan respon, mulai dari 1 yang menunjukkan "sangat tidak sesuai" sampai dengan 6 yang menunjukkan "sangat sesuai". Nilai koefisien reliabilitas alpha Cronbach 0,793.

Motivasi intrinsik diukur menggunakan adaptasi empat subkala dari Sport Motivation Scale-II (SMS-II) [24]. Faktor motivasi yang diukur adalah regulasi intrinsik (terinspirasi semata-mata dari minat dan kesenangan yang ditemukan seseorang dalam suatu kegiatan), regulasi terintegrasi (ketika seseorang telah sepenuhnya mengintegrasikan motivasi dalam dirinya), regulasi yang teridentifikasi (kegiatan tersebut masih dilakukan karena alasan ekstrinsik, misalnya untuk mencapai tujuan pribadi, yang diatur secara internal dan ditentukan sendiri), regulasi yang diintrojeksi (sumber motivasi eksternal yang sebelumnya telah diinternalisasi). Masing-masing subskala terdiri dari empat item. Skala menggunakan model jawaban Likert dengan enam pilihan respon, mulai dari 1 yang menunjukkan "sangat tidak sesuai" sampai dengan 6 yang menunjukkan "sangat sesuai". Nilai koefisien reliabilitas alpha Cronbach 0,900.

\subsection{Prosedur}

Penelitian ini diawali dengan mengajukan ijin penelitian ke Dinas kepemudaan, Olahraga, dan Pariwisata (Disporapar) Provinsi Jawa tengah, dan Komite Olahraga Nasional Indonesia (KONI) Provinsi Jawa Tengah. Selanjutnya, skala yang telah diadaptasi kemudian disusun menggunakan google form dan diedarkan kepada atlet melalui pelatih menggunakan aplikasi whatsapp. Penyebaran kuisioner dimulai pada tanggal 17 Februari sampai dengan 30 April 2021, dengan harapan cukup banyak responden yang dapat berpartisipasi dalam penelitian ini. Data yang telah terkumpul selanjutnya dianalisis menggunakan bantuan SPSS 25 .

\section{Hasil}

Deskripsi tingkat resiliensi, ketangguhan mental dan motivasi intrinsik atlet didasarkan atas statistik hipotetik. Dari hasil perhitungan mean hipotetik dan standar deviasi, selanjutnya dilakukan pengelompokan menjadi tiga kategori, yaitu kategori rendah, sedang, dan tinggi. Hasil perhitungan menunjukkan bahwa tingkat resiliensi atlet sebagian besar pada kategori sedang. Pada tingkat ketangguhan mental atlet, tidak ada yang berada pada kategori rendah. Ketangguhan mental atlet sebagian termasuk pada kategori tinggi dan sebagian pada kategori sedang. Selanjutnya pada tingkat motivasi intrinsik atlet hampir seluruh atlet memiliki motivasi intrinsic yang tinggi. Hasil lengkap dapat dilihat pada Tabel 1.

\subsection{Hubungan antar variabel}

Resiliensi berkorelasi positif dengan ketangguhan mental $(r=0,616)$ dan motivasi intrinsik $(r=0,466)$, yang menurut standar ukuran efek [25], adalah ukuran efek menengah hingga besar. Ketangguhan mental berkorelasi positif dengan motivasi intrinsik $(r=0,551)$ yang ukuran efeknya besar [25], yang disajikan pada Tabel 2. 
Tabel 1. Persentase kategori tingkat resiliensi, ketangguhan mental, dan motivasi intrinsik atlet selama pandemi covid 19

\begin{tabular}{lcccccc}
\hline \multirow{2}{*}{ Kategori } & \multicolumn{2}{c}{ Resiliensi } & \multicolumn{2}{c}{ Ketangguhan mental } & \multicolumn{2}{c}{ Motivasi intrinsik } \\
\cline { 2 - 6 } & $\Sigma$ & $\%$ & $\sum$ & $\%$ & $\sum$ & $\%$ \\
\hline Rendah & 2 & 9 & 0 & 0 & 0 & 0 \\
Sedang & 141 & 62,7 & 102 & 45,3 & 12 & 5,3 \\
Tinggi & 82 & 36,7 & 123 & 54,7 & 213 & 94,7 \\
Total & 225 & 100 & 225 & 100 & 225 & 100 \\
\hline
\end{tabular}

Tabel 2. Korelasi antar variabel

\begin{tabular}{lccc}
\hline & Resiliensi & Ketangguhan mental & Motivasi intrinsik \\
\hline Resiliensi & - & - & - \\
Ketangguhan mental & $0,616^{* *}$ & - & - \\
Motivasi intrinsik & $0,466^{* *}$ & $0,551^{* *}$ & - \\
\hline$* * p<0,001$ & & &
\end{tabular}

\subsection{Peran ketangguhan mental dan motivasi intrinsic terhadap resiliensi}

Regresi linier berganda digunakan untuk menentukan sejauh mana ketangguhan mental dan motivasi intrinsic memprediksi resiliensi. Hasil penelitian menunjukkan bahwa ketangguhan mental $(B=0,52, \mathrm{p}<0,001)$ dan motivasi intrinsik $(B=0,18, \mathrm{p}=0,004)$. Hasil tersebut diketahui bahwa masing-masing variabel bebas secara parsial mempunyai pengaruh yang signifikan terhadap variabel terikat. Artinya ketangguhan mental dan motivasi intrinsik secara parsial berpengaruh terhadap resiliensi atlet.

Diketahui pula bahwa besarnya nilai koefisien determinasi ditunjukan oleh nilai Adjusted $R$ Square $\left(R^{2}\right)$ yaitu sebesar 0,393 yang artinya bahwa variasi dari semua variabel bebas yaitu ketangguhan mental dan motivasi intrinsik dapat menerangkan variabel resiliensi sebesar 39,3\% sedangkan sisanya $60,7 \%$ diterangkan oleh variabel lain yang tidak diajukan dalam penelitian ini. Keduanya merupakan prediktor signifikan terhadap resiliensi $(\mathrm{F}=73,36, \mathrm{R} 2=0,393, \mathrm{p}<0,001$; lihat Tabel 3).

Selain koefisien determinasi juga didapat koefisien korelasi yang menunjukkan besarnya hubungan antara variabel bebas yaitu ketangguhan mental dan motivasi intrinsik dengan variable resiliensi, nilai $\mathrm{R}$ (koefisien korelasi) sebesar 0,631, nilai korelasi ini menunjukkan bahwa hubungan antara variabel bebas yaitu ketangguhan mental dan motivasi intrinsic dengan resiliensi termasuk dalam kategori kuat karena berada pada selang 0,6-0,8. Hubungan antara variabel bebas yaitu ketangguhan mental dan motivasi intrinsic dengan resiliensi bersifat positif, artinya jika variabel bebas semakin ditingkatkan maka resiliensi juga akan mengalami peningkatan.

Tabel 3. Analisis regresi linier berganda peran ketangguhan mental dan motivasi intrinsik terhadap resiliensi

\begin{tabular}{|c|c|c|c|c|c|c|c|c|}
\hline & \multirow{2}{*}{ Model } & \multicolumn{2}{|c|}{$\begin{array}{c}\text { Unstandardized } \\
\text { Coefficients }\end{array}$} & \multirow{2}{*}{$\begin{array}{c}\begin{array}{c}\text { Standardized } \\
\text { Coefficients }\end{array} \\
\text { Beta } \\
\end{array}$} & \multirow[t]{2}{*}{$\mathrm{t}$} & \multirow{2}{*}{ Sig. } & \multicolumn{2}{|c|}{ 95.0\% Confidence Interval for B } \\
\hline & & $\mathrm{B}$ & Std. Error & & & & Lower Bound & Upper Bound \\
\hline \multirow[t]{3}{*}{$\overline{1}$} & (Constant) & 2,441 & 2,203 & - & 1,108 & 0,269 & 2,441 & 2,203 \\
\hline & MT & 0,257 & 0,030 & 0,531 & 8,67 & 0 & 0,257 & 0,030 \\
\hline & MI & 0,101 & 0,038 & 0,162 & 2,646 & 0,009 & 0,101 & 0,038 \\
\hline
\end{tabular}

a. Dependent Variable: Res

$R^{2}=0,393, F=73,36, p<0,001$

\section{Pembahasan}

Krisis Covid-19 saat ini memunculkan ketidakpastian, dan berbagai ketidakpastian dikaitkan dengan kecemasan [26]. Tidak banyak penelitian yang mengkaji keterkaitan 
antara resiliensi, ketangguhan mental, dan motivasi intrinsik pada atlet, khususnya dalam situasi pandemi yang menimbulkan banyak ketidakpastian saat ini. Tujuan dari penelitian ini adalah untuk mengeksplorasi hubungan antara resiliensi, ketangguhan mental, dan motivasi intrinsik pada atlet kompetitif selama masa pandemi Covid 19. Berdasarkan hasil analisis, hipotesis terbukti bahwa (a) resiliensi dan ketangguhan mental berhubungan positif, (b) resiliensi berhubungan positif dengan motivasi intrinsik, (c) ketangguhan mental berhubungan positif dengan motivasi intrinsic, dan (d) baik ketangguhan mental dan motivasi intrinsik secara signifikan memprediksi resiliensi.

Hasil penelitian menunjukkan masih banyak atlet memiliki tingkat resiliensi yang belum cukup tinggi. Resiliensi merupakan proses dinamis di mana sistem biopsikososial kembali ke tingkat fungsi sebelumnya setelah gangguan yang disebabkan oleh stresor [13]. Oleh karena itu, atlet yang menjadi subyek dalam penelitian ini mungkin masih menggunakan proses resiliensi mereka untuk melakukan adaptasi positif, karena kesulitan yang mereka hadapi masih terus berlangsung.

Korelasi positif yang kuat antara resiliensi dan ketangguhan mental dapat menunjukkan adanya konsep parallel antara dua konstruk. Resiliensi dan ketangguhan mental berhubungan dengan adaptasi yang efektif, mengatasi, mempertahankan fungsi atau kinerja, dan berhasil meskipun mengalami kesulitan, tekanan, kemunduran, atau stres [27]. Konsep resiliensi telah menguraikan faktor pelindung ketahanan inti pada atlet, yang mana faktor-faktor tersebut banyak di antaranya sangat mirip dengan atribut ketangguhan mental (misalnya, kepercayaan diri) [6]. Hal ini didukung oleh temuan saat ini bahwa baik resiliensi dan ketangguhan mental, secara kolektif dan signifikan memprediksi stres. Sehingga keduanya dianggap memberikan kontribusi terhadap cara atlet mengatasi situasi sulit yang dihadapi.

Ketangguhan mental, di sisi lain, mungkin berlaku lebih khusus untuk stres yang dialami atlet selama pelatihan olahraga, kompetisi, dan pasca-kompetisi. Jadi, meskipun resiliensi mungkin memiliki peran dalam kaitannya dengan mengatasi stres, ketangguhan mental mungkin lebih penting untuk meniadakan atau menghindari efek merugikan dari stres di kalangan atlet dalam konteks olahraga, sedangkan resiliensi mungkin relevan terutama ketika mengalami kesulitan yang lebih parah yang mungkin terjadi di luar konteks pelatihan olahraga.

Temuan utama dari penelitian ini adalah bahwa peningkatan resiliensi dikaitkan dengan ketangguhan mental dan motivasi intrinsik yang lebih tinggi. Oleh karena itu, kami menyimpulkan bahwa pengaruh ketangguhan mental sebagai sumber resiliensi memiliki relevansi praktis, terutama karena sulitnya mendeteksi efek interaksi dengan desain penelitian non-eksperimental. Begitu juga bahwa motivasi intrinsik atlet memberikan pengaruh yang relevan terhadap resiliensi atlet. Hasil penelitian ini menunjukkan bahwa ketangguhan mental merupakan sumber daya yang bermanfaat yang membantu para atlet "bangkit" mengatasi kesulitan dan stress yang dihadapi.

Temuan bahwa ketangguhan mental terkait dengan tingginya resiliensi sesuai dengan pernyataan bahwa ketangguhan mental dikaitkan dengan adaptasi positif terhadap stres [28]. Sebagaimana di awal disampaikan bahwa menurut [10], resiliensi sebagai proses negosiasi, adaptasi, atau pengelolaan sumber stres atau trauma yang signifikan secara efektif. Hasil penelitian ini mendukung penelitian sebelumnya yang telah melaporkan bahwa atlet yang lebih tangguh secara mental mengalami tingkat stres yang lebih rendah. Atlet yang tangguh secara mental mungkin menilai stresor sebagai sesuatu yang kurang intens, dan menghasilkan pandangan yang lebih optimis serta respons stres yang lebih rendah [29]. Ini mungkin juga berhubungan dengan kemampuan superior mereka untuk 
mengendalikan pikiran dan emosi mereka [30], yang membantu menilai stresor atau kemampuan mereka untuk menggunakan strategi koping yang lebih efektif [31]. Sebagai alternatif, individu yang tangguh secara mental dapat menggunakan berbagai strategi psikologis (misalnya, teknik relaksasi, self-talk, citra mental) yang membantu mereka ketika mereka menghadapi stresor atau mengalami stres [32].

Disamping ketangguhan mental, motivasi intrinsic menjadi salah satu prediktor resiliensi atlet. Motivasi merupakan faktor utama dalam olahraga prestasi yang dapat berperan menjamin kelangsungan proses latihan karena kemampuannya memberikan arah pada tujuan berlatih sehingga aktivitas olahraga lebih efektif dalam mencapai tujuan prestasinya. Kehilangan motivasi dapat menyebabkan orientasi terhadap tujuan menjadi lemah. Terdapat dua jenis atau tipe motivasi, yaitu motivasi intrinsik (berasal dari dalam diri) dan motivasi ekstrinsik (berasal dari luar diri). Motivasi intrinsik memiliki peranan yang lebih besar pada individu. Motivasi intrinsik adalah pilihan untuk melakukan sesuatu karena senang atau menyukainya [33]. motivasi intrinsik adalah keterlibatan dalam suatu aktivitas karena aktivitas itu sendiri dan untuk kesenangan serta kepuasan yang timbul dari keikutsertaannya, ketika seseorang berusaha untuk mencapai atau menciptakan sesuatu atau untuk melampaui diri sendiri [34].

Atlet dengan motivasi intrinsik yang sangat tinggi memengaruhi dirinya dalam mengembangkan kemampuan resiliensi sehingga mereka mampu untuk menilai, mengatasi dan meningkatkan diri ataupun mengubah dirinya dari keterpurukan atau kesengsaraan dalam hidup. Sebagaimana hasil penelitian [35] bahwa motivasi intrinsik merupakan prediktor yang signifikan dalam melihat tingkat resiliensi psikologis seseorang. Atlet yang memiliki tingkat motivasi intrinsik yang tinggi dapat terdorong untuk melakukan sesuatu dan mengetahui manfaat apa yang didapat ketika melakukan suatu tugas. Individu yang memiliki dorongan kuat dari dalam dirinya ini memiliki kebebasan dalam beraktivitas, memiliki perasaan efektif dalam melakukan suatu aktivitas dan individu merasa ada perasaan disayangi dan diperhatikan oleh lingkungan sekitar [33].

Penelitian ini menunjukkan bahwa mengembangkan pola pikir ketangguhan mental dan memperkuat motivasi intrinsik atlet dapat mewakili target intervensi untuk program adaptasi yang tangguh selama masa pandemi yang masih terus berlangsung. Hasil penelitian ini juga memberikan gambaran bahwa ketangguhan mental dan motivasi intrinsik adalah atribut yang menarik dan diinginkan bagi banyak atlet, karena hal itu berkaitan erat dengan pengalaman sehari-hari mereka. Oleh karena itu, penelitian selanjutnya dapat menentukan sejauh mana intervensi yang bertujuan untuk membangun sumber daya atlet baik sumberdaya sosial yang mungkin berpengaruh dan fungsi interpersonal, seperti hubungan dengan pelatih dan keluarga, dalam upaya mengembangkan aspek psikologis atlet. Penelitian selanjutnya juga dapat diarahkan untuk menentukan hasil atau indikator resiliensi dan ketangguhan mental (misalnya, perilaku) sebagai fungsi dari jenis dan situasi olahraga yang membutuhkan resiliensi dan ketangguhan mental dalam olahraga. Penelitian yang membedakan resiliensi dan ketangguhan mental juga diperlukan, seperti relevansi, aplikasi, dan hasil yang terkait dengan setiap konstruk dalam beragam konteks olahraga dan non-olahraga.

Ada beberapa keterbatasan dalam penelitian ini. Secara khusus, desain cross-sectional membatasi kesimpulan kausalitas antara variabel. Disamping itu, terkait dengan motivasi, perlu mengidentifikasi peran motivasi ekstrinsik yang mungkin juga berpengaruh pada resiliensi atlet. 


\section{Kesimpulan}

Hasil penelitian ini mendukung adanya keterkaitan antara resiliensi, ketangguhan mental dan motivasi intrinsic pada atlet kompetitif. Temuan ini juga memberikan bukti bahwa ketangguhan mental dan motivasi intrinsic merupakan predictor tingkat kemampuan resiliensi atlet. Penelitian selanjutnya perlu dilakukan untuk mengetahui faktor lain yang mungkin berpengaruh terhadap resiliensi atlet, ataupun faktor yang memperkuat aspek psikologis lain yang dibutuhkan atlet. Hasil penelitian ini diharapkan dapat memberikan arah bagi program intervensi peningkatan prestasi atlet melalui penguatan aspek psikologis atlet.

\section{Referensi}

[1] C. L. Reardon et al., "Mental health in elite athletes: International Olympic Committee consensus statement (2019)," Br J Sports Med, vol. 53, no. 11, pp. 667-699, Jun. 2019, doi: 10.1136/bjsports-2019-100715.

[2] S. K. Brooks et al., "The psychological impact of quarantine and how to reduce it: rapid review of the evidence," The Lancet, vol. 395, no. 10227, pp. 912-920, Mar. 2020, doi: 10.1016/S0140-6736(20)30460-8.

[3] P. Wu et al., "Alcohol Abuse/Dependence Symptoms Among Hospital Employees Exposed to a SARS Outbreak," Alcohol and Alcoholism, vol. 43, no. 6, pp. 706-712, Nov. 2008, doi: 10.1093/alcalc/agn073.

[4] W. D. S. Killgore, E. C. Taylor, S. A. Cloonan, and N. S. Dailey, "Psychological resilience during the COVID-19 lockdown," Psychiatry Res, vol. 291, p. 113216, Sep. 2020, doi: 10.1016/j.psychres.2020.113216.

[5] C. H. Liu, E. Zhang, G. T. F. Wong, S. Hyun, and H. "Chris" Hahm, "Factors associated with depression, anxiety, and PTSD symptomatology during the COVID-19 pandemic: Clinical implications for U.S. young adult mental health," Psychiatry Res, vol. 290, p. 113172, Aug. 2020, doi: 10.1016/j.psychres.2020.113172.

[6] D. Fletcher and M. Sarkar, "A grounded theory of psychological resilience in Olympic champions," Psychology of Sport and Exercise, vol. 13, no. 5, pp. 669-678, Sep. 2012, doi: 10.1016/j.psychsport.2012.04.007.

[7] S. Gupta and P. J. McCarthy, "Sporting Resilience During COVID-19: What Is the Nature of This Adversity and How Are Competitive Elite Athletes Adapting?," Front. Psychol., vol. 12, 2021, doi: 10.3389/fpsyg.2021.611261.

[8] M. A. Barton, M. Christianson, C. G. Myers, and K. Sutcliffe, "Resilience in action: leading for resilience in response to COVID-19," BMJ Leader, p. leader, May 2020, doi: 10.1136/leader-2020-000260.

[9] C. Polizzi, S. J. Lynn, and A. Perry, "Stress and coping in the time of covid-19: pathways to resilience and recovery," Clinical Neuropsychiatry, vol. 17, no. 2, 2020.

[10] G. Windle, "What is resilience? A review and concept analysis," 2011, doi: 10.1017/S0959259810000420.

[11] G. A. Bonanno and E. D. Diminich, "Annual Research Review: Positive adjustment to adversity - trajectories of minimal-impact resilience and emergent resilience," Journal of Child Psychology and Psychiatry, vol. 54, no. 4, pp. 378-401, 2013, doi: https://doi.org/10.1111/jcpp.12021.

[12] N. Galli and S. P. Gonzalez, "Psychological resilience in sport: A review of the literature and implications for research and practice," International Journal of Sport and Exercise Psychology, vol. 13, no. 3, pp. 243-257, Jul. 2015, doi: 10.1080/1612197X.2014.946947.

[13] Y. Hill, R. J. R. Den Hartigh, R. R. Meijer, P. De Jonge, and N. W. Van Yperen, "Resilience in sports from a dynamical perspective.," Sport, Exercise, and Performance Psychology, vol. 7, no. 4, pp. 333-341, Nov. 2018, doi: 10.1037/spy0000118. 
[14] R. Codonhato et al., "Resilience, stress and injuries in the context of the Brazilian elite rhythmic gymnastics," PLOS ONE, vol. 13, no. 12, p. e0210174, Dec. 2018, doi: 10.1371/journal.pone.0210174.

[15] J. Meggs, J. Golby, C. Mallett, D. Gucciardi, and R. Polman, "The cortisol awakening response and resilience in elite swimmers," International Journal of Sports Medicine, vol. 37, no. 02, pp. 169-174, 2016.

[16] R. Chacón-Cuberos, M. Castro-Sánchez, J. A. Pérez-Turpin, E. M. Olmedo-Moreno, and F. Zurita Ortega, "Levels of Physical Activity Are Associated With the Motivational Climate and Resilience in University Students of Physical Education From Andalucía: An Explanatory Model," Front. Psychol., vol. 10, 2019, doi: 10.3389/fpsyg.2019.01821.

[17] R. G. Cowden, A. Meyer-Weitz, and K. Oppong Asante, "Mental Toughness in Competitive Tennis: Relationships with Resilience and Stress," Front. Psychol., vol. 7, 2016, doi: 10.3389/fpsyg.2016.00320.

[18] M. Sheard, Mental Toughness: The Mindset Behind Sporting Achievement. Routledge, 2012.

[19] D. F. Gucciardi, S. Gordon, and J. A. Dimmock, "Advancing mental toughness research and theory using personal construct psychology," International Review of Sport and Exercise Psychology, vol. 2, no. 1, pp. 54-72, Mar. 2009, doi: 10.1080/17509840802705938.

[20] S. Arora, "Achievement motivation and resilience among student athletes (Doctoral dissertation)." 2015.

[21] D. F. Gucciardi, "Mental toughness profiles and their relations with achievement goals and sport motivation in adolescent Australian footballers," Journal of Sports Sciences, vol. 28, no. 6, pp. 615-625, Apr. 2010, doi: 10.1080/02640410903582792.

[22] B. W. Smith, J. Dalen, K. Wiggins, E. Tooley, P. Christopher, and J. Bernard, "The brief resilience scale: Assessing the ability to bounce back," Int. J. Behav. Med., vol. 15, no. 3, pp. 194-200, Sep. 2008, doi: 10.1080/10705500802222972.

[23] M. Sheard, J. Golby, and A. van Wersch, "Progress Toward Construct Validation of the Sports Mental Toughness Questionnaire (SMTQ)," European Journal of Psychological Assessment, vol. 25, no. 3, pp. 186-193, Jan. 2009, doi: 10.1027/1015-5759.25.3.186.

[24] L. G. Pelletier, M. A. Rocchi, R. J. Vallerand, E. L. Deci, and R. M. Ryan, "Validation of the revised sport motivation scale (SMS-II)," Psychology of Sport and Exercise, vol. 14, no. 3, pp. 329-341, May 2013, doi: 10.1016/j.psychsport.2012.12.002.

[25] J. Cohen, “A power primer,” Psychological bulletin, vol. 112, no. 1, p. 155, 1992.

[26] D. W. Grupe and J. B. Nitschke, "Uncertainty and Anticipation in Anxiety," Nat Rev Neurosci, vol. 14, no. 7, pp. 488-501, Jul. 2013, doi: 10.1038/nrn3524.

[27] S. A. Hosseini and M. A. Besharat, "Relation of resilience whit sport achievement and mental health in a sample of athletes," Procedia - Social and Behavioral Sciences, vol. 5, pp. 633-638, 2010, doi: 10.1016/j.sbspro.2010.07.156.

[28] D. F. Gucciardi, S. Gordon, and J. A. Dimmock, "Development and preliminary validation of a mental toughness inventory for Australian football," Psychology of Sport and Exercise, vol. 10, no. 1, pp. 201-209, Jan. 2009, doi: 10.1016/j.psychsport.2008.07.011.

[29] M. Kaiseler, R. Polman, and A. Nicholls, "Mental toughness, stress, stress appraisal, coping and coping effectiveness in sport," Personality and Individual Differences, p. 7, 2009.

[30] L. Crust, "The relationship between mental toughness and affect intensity," Personality and Individual Differences, vol. 47, no. 8, pp. 959-963, Dec. 2009, doi: 10.1016/j.paid.2009.07.023.

[31] L. Crust and R. Keegan, "Mental toughness and attitudes to risk-taking," Personality and Individual Differences, vol. 49, no. 3, pp. 164-168, Aug. 2010, doi: 10.1016/j.paid.2010.03.026. 
[32] P. Mattie and K. Munroe-Chandler, "Examining the Relationship Between Mental Toughness and Imagery Use," Journal of Applied Sport Psychology, vol. 24, no. 2, pp. 144-156, Apr. 2012, doi: 10.1080/10413200.2011.605422.

[33] E. L. Deci and R. M. Ryan, "Intrinsic Motivation," in The Corsini Encyclopedia of Psychology, American Cancer Society, 2010, pp. 1-2. doi: 10.1002/9780470479216.corpsy0467.

[34] R. J. Vallerand, "Intrinsic and extrinsic motivation in sport and physical activity: A review and a look at the future," in Handbook of sport psychology, 3rd ed, Hoboken, NJ, US: John Wiley \& Sons, Inc., 2007, pp. 59-83.

[35] M. Ghasem and M. Hosseinchari, "Psychological resilience and intrinsic-extrinsic motivation: The mediating role of self-efficacy," Developmental Psychology: Journal of Iranian Psychologists, vol. 8, no. 33, pp. 61-72, 2012. 